\title{
International Development Banks as Centers of Technological Exchange: Is Future Here?
}

\author{
Yana L. Gobareva ${ }^{1, *}$, Olga Yu. Gorodetskaya ${ }^{1}$, Marina V. Karp ${ }^{2}$, Igbal A. Guliev ${ }^{3}$ \\ ${ }^{1}$ Department of Data Analysis, Decision-Making and Financial Technology, Financial University under the Government of the Russian \\ Federation, Moscow, Russia \\ ${ }^{2}$ Department of Accounting, Audit and Taxation, State University of Management, Moscow, Russia \\ ${ }^{3}$ International Institute of Energy Policy and Diplomacy, MGIMO University, Moscow, Russia
}

Received March 15, 2021; Revised April 30, 2021; Accepted May 26, 2021

\section{Cite This Paper in the following Citation Styles}

(a): [1] Yana L. Gobareva, Olga Yu. Gorodetskaya, Marina V. Karp, Igbal A. Guliev, "International Development Banks as Centers of Technological Exchange: Is Future Here?," Universal Journal of Accounting and Finance, Vol. 9 , No. 3, pp. 329 - 335, 2021. DOI: 10.13189/ujaf.2021.090306.

(b): Yana L. Gobareva, Olga Yu. Gorodetskaya, Marina V. Karp, Igbal A. Guliev (2021). International Development Banks as Centers of Technological Exchange: Is Future Here?. Universal Journal of Accounting and Finance, 9(3), 329 - 335. DOI: 10.13189/ujaf.2021.090306.

Copyright $\bigcirc 2021$ by authors, all rights reserved. Authors agree that this article remains permanently open access under the terms of the Creative Commons Attribution License 4.0 International License

\begin{abstract}
The problems of technological exchange and technological development are becoming the most important for all groups of countries. Developed countries want to maintain their dominant position, developing countries try to catch them up, and the least developed countries try not to be a raw materials appendage of both the first ones and second ones. Technological convergence can become the answer to the challenges for all countries. The article's aim is to form theoretical approaches to technological convergence with the development banks participation. The main challenge of the article is the lack of statistical data on the subject, just as the novelty of the scientific field covering technologic convergence itself. The main article's results are the development of a more equitable technological convergence model, the technology exchange model in Asia, the financial mechanism's development for technological convergence through development banks and proposals for development banks entering the suggested technological convergence track. Thus, the answer to the question posed in the title is negative, as modern development banks cannot effectively cope with the technological exchange. The key contribution of the article is the creation of the theoretic model for the Asian international development institutions on the technology exchange mechanisms, just as the model of attracting financial resources to the project in the field of technology, interconnected with each other.
\end{abstract}

Keywords Development Banks, Technology Exchange, Convergence, Strategy, Asia

\section{Introduction}

Today, international development banks (IDBs) play an important role in the development of countries, especially the least developed countries of the regions where these banks operate. A significant contribution to these institutions' activities is made by financial instruments such as lending, formation and collateral search for credit lines, the investment attractiveness' assessment, the search for new raising capital forms (including in the financial technologies' field). At the same time, the international development banks' activities remain insufficiently effective: for the most part, the development banks' capital is not enough to stimulate all regional capital recipients' growth $[10,11]$. Their potential is limited, which is inevitable, as these institutions' capital is formed by excess capital of the developed countries and the most dynamically developing economies. Taking into account that resources are limited, excess capital cannot be significant and it cannot be compared with the capital needed for the development.

This leads to the conclusion development banks need to 
seek new formats for cooperation with developing countries. These formats should be directed at fulfilling UNCTAD's sustainable development goals $[4,11]$ and at searching for national income's sources for capital recipient countries. Within the research, the authors suggest turning to cooperation in the sphere of the technology and their transfer to the least developed countries on agreed terms. The authors highlight the difficulties with which this cooperation model faces, but the authors also mark out the advantages which this model can give. The authors offer financial cooperation models with the IDBs and national banks use. Being a cooperation fundamental region, the authors mark out the Asia-Pacific region, because today it is developing most dynamically and offers the most flexible banking tools. Deep integration of the region's countries into the regional institutions, and also the presence of clearly specified regional technological leaders, especially taking into account these leaders specialize in certain technology sectors (for example, Japan specializes in high technology in the PC sector, China specializes in a wide range of high-tech products, including polymers, South Korea specializes in the microprocessors' field, Malaysia specializes in the light industry field) [5].

The hypothesis of the research is that the development banks can significantly improve the technological cooperation and exchange between the developing economies, which today is strangled by the low quality of the institutional infrastructure for it. In order to prove the hypothesis the authors use empirical methods of analysis, as the statistical methods are not suitable for the analysis of the theoretical basis for the cooperation.

\section{Literature Review}

The role of the development banks in the global economy isn't discussed often, as the major conception sticks to the opinion, that their role is one and only - the support of the development [17]. This conception does offer real opportunities for the developing countries, but in the dynamically developing regions, Asia, for instance, the development banks don't have enough capital for the direct support of development and need new ways to support the regional development [1]. Hence, the discussion on the new role of the development banks starts to develop [14]. But in both cases the authors concentrate on the technology development stimulation, not on their transfer through the development banks. The idea of development banks as intellectual centers in different spheres is partially described in [7], where the idea of "smart banks" is proposed. At the same time, the idea is underdeveloped, so the authors of this paper decided to concentrate on the aspect of technology transfer through development banks.

\section{Methodology}

The research methodology is based on an empirical approach to the analysis of the technological exchange process in the view point of its advantages and disadvantages in its modern form. Having identified the most problematic aspects of technological exchange and the advantages which it brings for various groups of countries, it becomes possible to develop a mechanism for involving development banks in this process.

In connection with the theoretical nature of the research, it is necessary to present a methodological work's scheme (Figure 1).

Thus, despite the theoretical nature of the research, its practical significance is great for development banks and the least developed countries (LDCs).

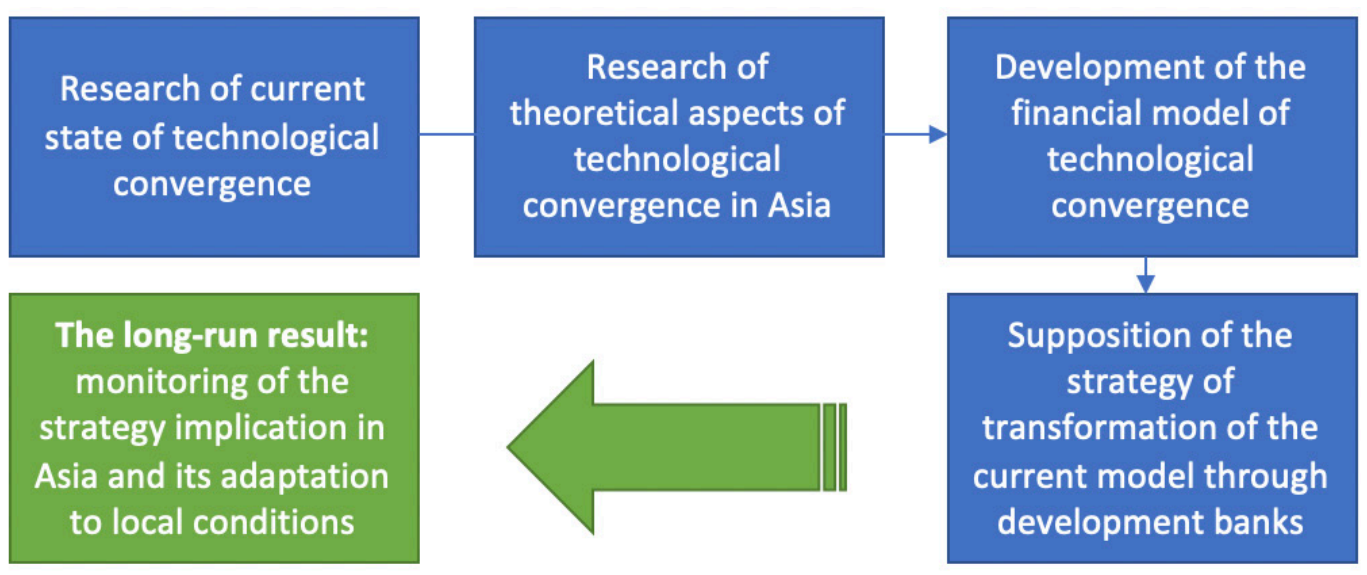

Figure 1. Methodological scheme of the research (developed by the authors) 


\section{Results}

As it was mentioned above, there is a series of deep problems in the technological exchange process in Asia's and the world's space as a whole. These problems are especially obvious within the research of the technological convergence prospects (within this article it is synonymous with technological exchange) through the international institutions' prism. Let us describe these problems:

1) During the creating of the Bretton Woods financial system institutions and its institutions, technological exchange and its realization were little taken into account. Subsequently, a series of institutions were formed, such as the World Intellectual Property Organization and a number of regional agreements, included clauses on the intellectual property protection, such as the Comprehensive Progressive Trans-Pacific Partnership (CTPP), or the Comprehensive Regional Economic Partnership (WTEC). These institutions create significant restrictions on technological exchange, which was one of the historical paths to use illegally somebody's intellectual property [8]. Besides, these organizations created a number of restrictions for further cooperation in the field of exchange and technologies development, as they create conditions for slowing down the less developed countries' technological development; because in the short term the technologies development is more costly than buying ready-made high-tech goods from their manufacturers (technologically more developed states).

2) Companies producing high-tech products determine the global economy's development. Today, a number of companies, possessing high technologies, for example, in the field of medicine (we are talking about American companies) create conditions for other countries' technological isolation, for example, within the TPP. China's high-tech companies operate the same way [13]. It is so because commercial companies pursue their own profits formation, while for developing countries this model causes losses and does not allow them to begin development along the technological path. At the same time, international institutions do not stimulate technological convergence.

3) Financial instruments' lack in the technological exchange field. Today, there are no unified approaches to financing high technologies development. In the whole, there are several basic approaches: public research funding, private financing, and co-financing by both actors. The financing developing process through crowdfunding has begun, but the process has not yet been debugged. Wherein, there is not a single tool that can effectively raise funds for the high technologies development at the international level; moreover, we are not even talking about international financing mechanisms, even joint research centers are rare today [16].

4) There is the assessing difficulty of the new technologies cost, and that's why it is impossible to accurately determine how significant assistance is provided to developing countries in the technological convergence process [3].

Despite the existing problems, technological convergence development is seen as necessary to create conditions for further developing countries' development. The Asian region is most interesting in this regard because there are countries in this region which have achieved their economies' active development through high technologies development.

1) High technologies assist in the development of the economy's most sectors on a more sustainable track [12]. The economy's global transformation prioritizes goods with high added value: this is indicated by both increased regulation of the goods origin rules and a change in global value chains. All developed economies have a set of unique benefits or services which allow them to receive super-profits; in this context, unique benefits, such as patents, become the basis of the economy's welfare and a generating source of a steady income stream to the economies producing such goods.

2) High technology is one of the most cost-effective products on the modern international market, and it is also one of the most protected. In the context of the high technology development, the high-tech products' production requires high costs for the infrastructure creation, the development of a wide highly skilled workers base, the natural resources costs [9]. Thus, the high-tech products' production costs are high, but even in these conditions, the benefits for the economy are high. The high technology producing cost is also high, but after creating the product, it does not create a negative revenue stream (it does not require production costs, which are carried out by less developed countries): it generates mainly revenues in the royalties form on patents and innovations, and it also increases the products' competitiveness of the country developer, while the material product manufacturing costs are partially transferred to less developed countries where the goods are produced to the corporate sector too. Thus, the profitability of the high technology production for the state is higher than the profitability of the high-tech products' production, but it, in turn, is higher than the profitability of the goods' production with low added value.

3) High-tech development allows developing countries to get on the innovative development track, which leads to narrowing the gap between developed and developing countries. This effect is a consequence of the previous one, as it is based on the fact that the high rent received from high technologies (products) 
allows to increase the national developing countries' income. Due to the low base effect, they catch up with developed countries.

4) Development banks do not play yet an important role in the regional economies development: using them as technology transfer mechanisms, this will increase their capital, expressed in the margin from royalties on transferred patents, and in their credibility increase among the least developed countries, being not only as financing sources, as it is observed today (the larger the development bank's capital is, the greater the role it plays in the region), but as direct development sources. An economy assessment from the viewpoint of its readiness to produce high-tech products, and the mechanisms' formation for the income redistribution on manufactured goods/services, will allow development banks to create a development support system in the region, and to reduce regional imbalances between the most and least developed economies. Thus, there is a departure from the model of the influence through capital; there is this model's transformation into influence through technology.
Nevertheless, both the disadvantages and the advantages highlighted by the authors are characteristic for the global or regional technological convergence model; nowadays, this model existence is impossible due to the effective mechanism lack for its realization. The authors suggest a mechanism of its functioning and financing on the example of Asian monetary and financial institutions, primarily development banks (Figure 2).

The scheme is a technology distribution and redistribution which occurs between developed and developing countries, and which can be clearly traced historically, but without the development banks participation $[2,6]$. The second system's circuit (orange arrows) is an analogue of the technologies distribution between developed and developing countries, only developing countries act as a technology donor. Obviously, countries receive the least amount of money if they are farthest from the chain's beginning, so the development banks role should be to form a leverage mechanism of their capabilities and dynamically developing countries capabilities too.

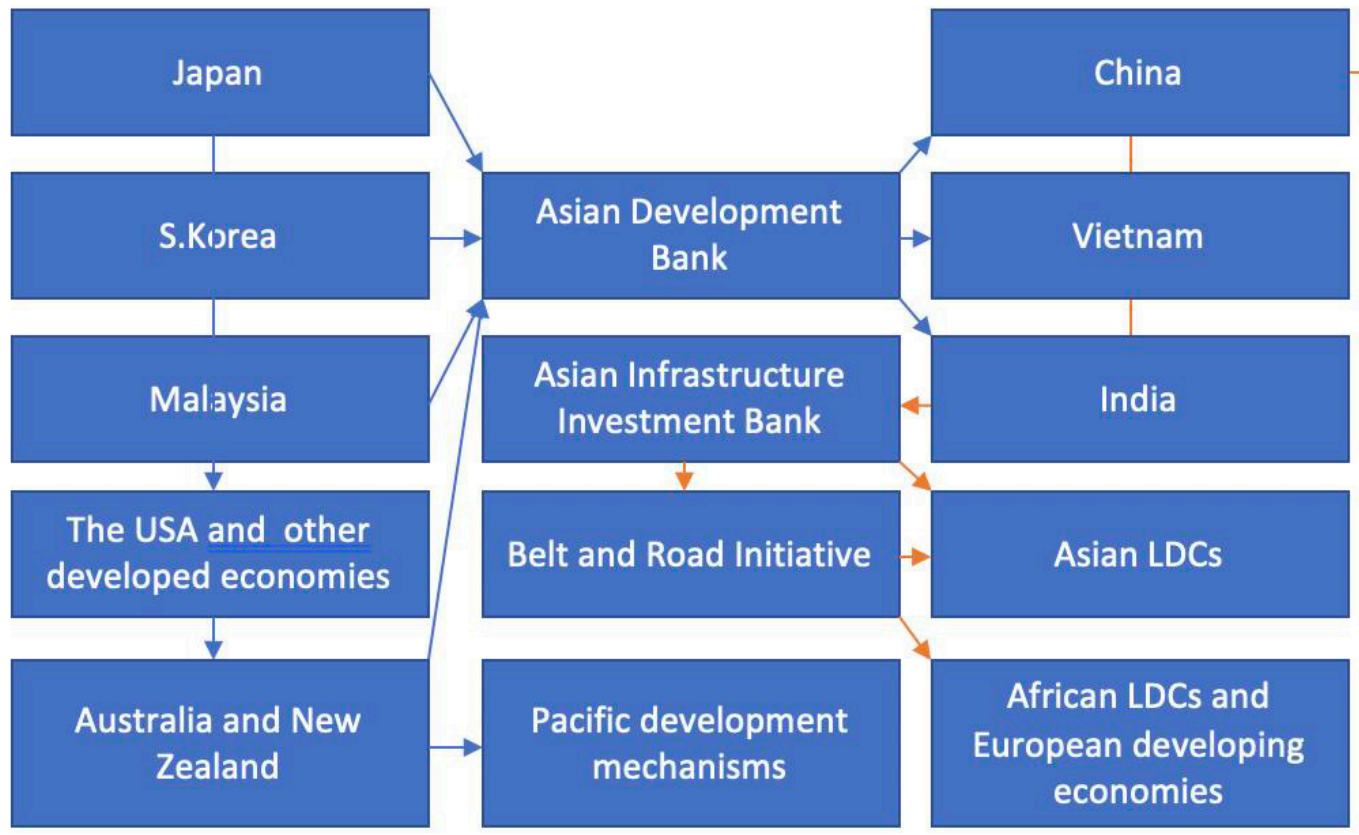

Figure 2. Interaction Scheme between countries and the Asian monetary and financial institutions in the technological convergence process (developed by the authors) 


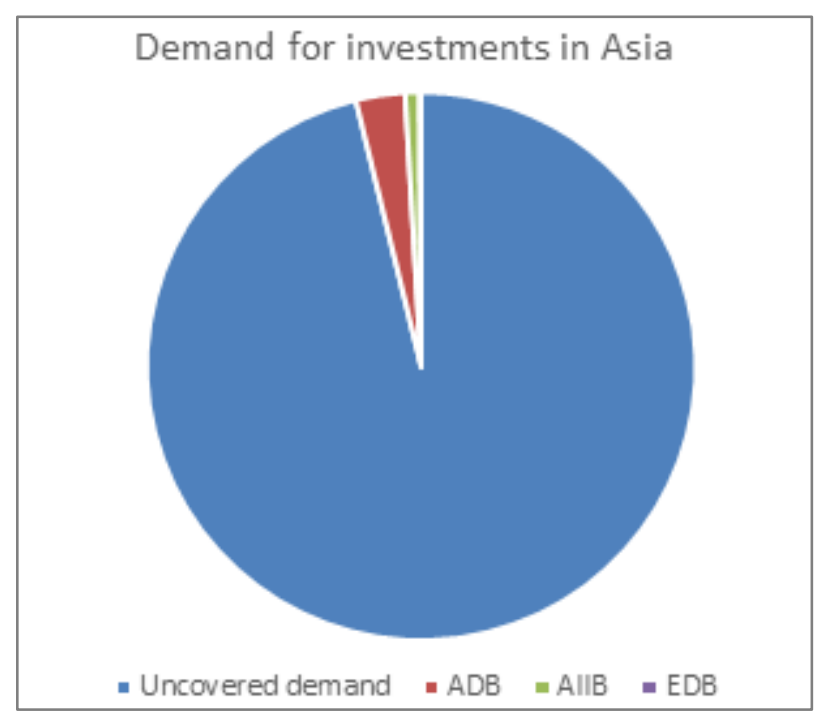

Figure 4. Demand for investments in Asia (developed by authors, based on data from $[18,19,20])$.

The current situation around use of the financial and technological possibilities of the Asian development banks is rather complicated. From one side, all the mentioned banks have numerous projects in Asia, the ADB actively supports the research projects, both by consulting and by financing. The AIIB contributes to the development of infrastructure, in this regard providing basis for the future development of the economies, including provision of the technological solutions in energy, construction, green development and social institutions development. The Pacific mechanism are more of a regulative character in the sphere of intellectual property, while Belt and Road Initiative covers a wide range of projects and the assessment of its significance to technological convergence is blurry and not reliable. From the other hand, none of the mentioned institutions have introduced special mechanisms for technological convergence for there are several major reasons: 1) these mechanisms are required by the less developed economies and the most dynamically developing economies, which play the major role in these institutions are not interested in free technology sharing; 2 ) the resources of the development banks are limited and the demand for them is higher in the sphere of infrastructure and energy as the sectors with the highest returns (figure 4).

At the same time, the BRI has a high potential for supplying resources for the Asian development - the analysis of the projects of the initiative in 2018-2019 allows to conclude, that the overall yearly demand for investments was covered $165 \%$ (counted by authors, based on the data [21]). Hence the reasoning that the development banks don't have enough financial resources for stimulating the sectors with lower returns in Asia proves to be true only partially.

In this regard, it's necessary to mention that none of the states in Asia has introduced any restrictions on cooperation with the development banks [17, 22]. The only existing barriers are that the development banks themselves choose the most sustainability impactable projects, paying special attention to the mentioned spheres with high returns. The major reason for the absence of such mechanisms remains the same as in the mid-twentieth century - the non-willingness to share technological solutions of the better developed economies.

As a result, the authors concentrated on the ways to introduce the profits model, in order to substantialise and pinpoint the main benefits of technological cooperation for the developed and most dynamically developing economies. The technological convergence's financial mechanism can be represented as continuous cash flow, and its parts settle at the different cycle's stages (Figure $3)$.

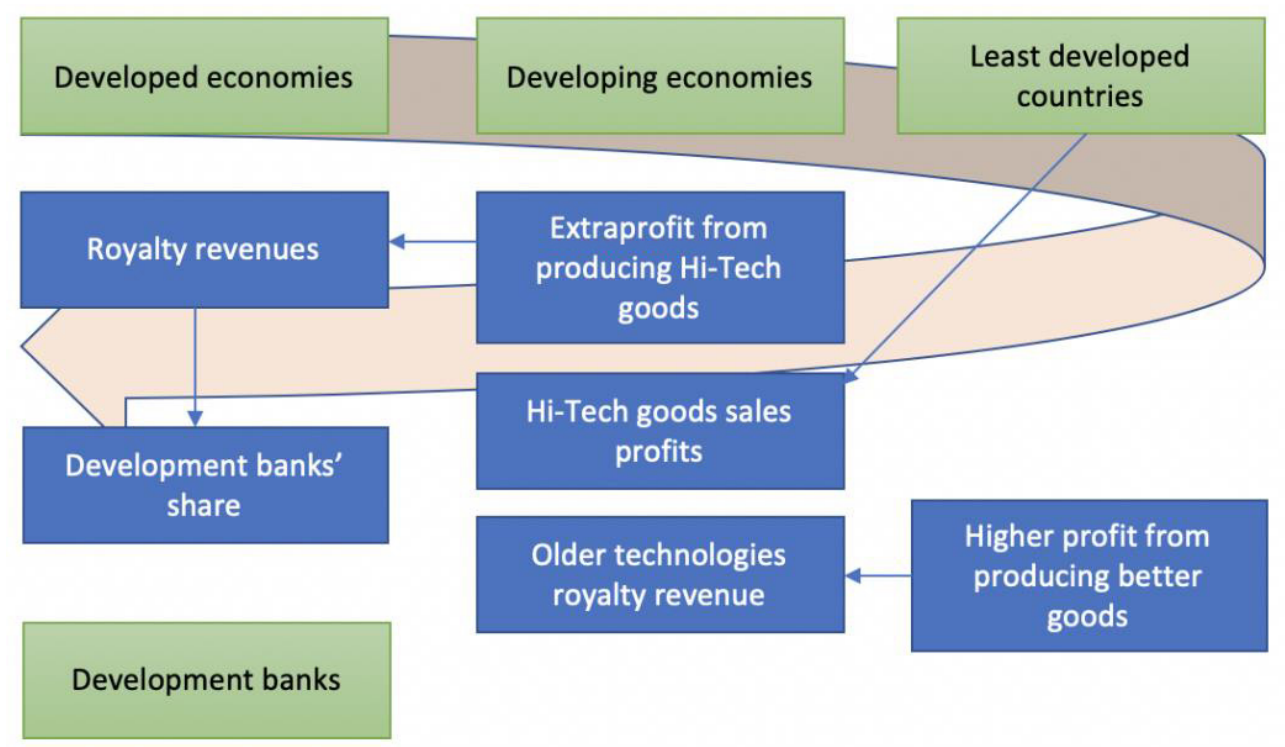

Figure 3. The financial flows cycle on the background of the technological convergence cycle (developed by the authors) 
As shown in Figure 3, the technological convergence cycle (big arrow) begins in developed countries and ends there by: a) exporting technology to developing countries; b) the basic technologies export to least developed countries; c) the low value-added products' production in the least developed countries; d) production of the high-tech products in developing countries; these high-tech products are made of LDCs raw materials; e) the new technologies development with the high-tech products' help from developing countries in the developed countries. This cycle must be interrupted with the development banks help, which will redistribute the developed countries' incomes from royalties through their mechanisms in LDCs support, and transfer higher-level technologies to LDCs.

\section{Discussion}

The suggested technological convergence model is theoretical and it has an alternative nature to the current development model. It is necessary to add that, nowadays, this model is poorly realized; that's why to realize it and it is necessary to develop development banks' financial mechanisms and technological cooperation mechanisms in developing countries. The authors offer measures which will assist to achieve the Sustainable Development Goals [15]:

1) Development and emission technological bonds by development banks: accumulated funds will be directed to buy developed countries' patents.

2) The formation of a mechanism for the patents' distribution between developing countries in accordance with their technological development level: the lower technological level is, the more basic technologies' patents country receives; the higher technological level is, the fewer patents country receives, but the more patents for high-tech products such country will be given;

3) The control over the patents use is vested in development banks: it is necessary to avoid the technologies monopolization by one or several companies; it is necessary to establish a mechanism for open access to a patent within a developing country without copyright infringement, etc.

4) Banks use the royalties received on patents to finance the new patents' purchase, and they also pay the patents' cost or royalties within the use, rather than an acquisition to their owners.

This will help to reduce poverty in developing countries, to create more jobs in both developing and least developed countries, to reduce inequality. These measures will also assist the green energy society's formation (many patents of recent years are devoted to green energy development) and the creation of more effective international institutions.

\section{Conclusions}

The development banks' tools are one of the most promising ways to narrow the technological and economic gap in the world.

Without the development banks' participation, technological exchange only strengthens the global technology imbalance and supports the developed countries hegemony.

It is necessary to start testing the offered theoretical model of technological convergence with Asian countries, as, in the Asia-Pacific region, there is a presence of all the necessary institutions for effective technological convergence, and in Asia, and the most technologically developed developing countries are located.

The basis for a new technological convergence form should become a more equitable financial flows' distribution through development banks.

Development banks should also develop a mechanism sufficient to realize this strategy, the first step of which should be the assets' formation from patents and dividing them into categories according to the technology level. It is also necessary to create a patents quota system, in accordance with this system they will be distributed among the development banks.

Thus, the technological development's future has not been achieved yet; moreover, there will be a long and painful way to turn it into reality.

\section{REFERENCES}

[1] Beniflah M., Kai-Wen I .V., Kaplan A., Santdasani A., "The AIIB and the Future of Multilateral Infrastructure Financing", "World House Student Fellows 2016-2017”, 2018, pp. 1-57. https://global.upenn.edu/sites/default/files/perry-world-hous e/AIIBReportForCampusCopy.pdf (accessed Feb. 2, 2021).

[2] Chander A., Sunder M., "The Battle to Define Asia's Intellectual Property Law: From TPP to RCEP”, UC Irvine law review, vol. 8, no. 3, pp. 331-362, 2018. https://www.law.uci.edu/lawreview/vol8/no3/Online_Chand er\%20Sunder.pdf.

[3] Chang J., Hung M., Tsai F., "Valuation of intellectual property: A real option approach", Journal of Intellectual Capital, vol. 6, no. 3, pp.339-356, 2005. DOI: $10.1108 / 14691930510611094$.

[4] Engen L., Prizzon A., “A guide to multilateral development banks" in Overseas Development Institute, ODI, 2018, pp. $1-92$.

[5] Ervani E., Widodo T., Purnawan M.E., "Comparative Advantage and Trade Specialization of East Asian Countries: Do East Asian Countries Specialize on Product Groups with High Comparative Advantage?", International Business Research, vol. 12, no. 2, pp. 113-134, 2019. DOI: 10.5539/ibr.v12n2p113. 
[6] Ezell S., Cory N., "The Way Forward for Intellectual Property Internationally”, ITIF, https://itif.org/publications/ 2019/04/25/way-forward-intellectual-property-internationall y (accessed Feb. 2, 2021).

[7] Fernández-Arias E., Hausmann R., Panizza U., "Smart Development Banks" in Inter-American Development Bank, IDB-WP-1047 ed., IDB, 2019, pp. 1-49.

[8] Flynn S.M., Baker B.K., Kaminski M.E., Koo J., "The U.S. Proposal for an Intellectual Property Chapter in the Trans-Pacific Partnership Agreement", SSRN Electronic Journal, vol. 28, no. 1, pp. 105-202, 2012. DOI: $10.2139 /$ ssrn.2185402.

[9] Kimura F., Obashi A., "Production Networks in East Asia: What We Know So Far" in Asian Development Bank Institute Working Paper Series, no. 320 ed., ADBA, 2011, $1-30$.

[10] Nelson R.M., "Multilateral Development Banks: Overview and Issues for Congress" in Congressional Research Service, R41170, CRS report, 2020, pp. 1-22.

[11] Prizzon A., Humphrey C., Kaul I., Kodera K., McKechnie A., Rogerson A., "Six recommendations for reforming multilateral development banks" in Overseas Development Institute, ODI, 2017, pp. 1-34.

[12] Reza S., Hongzhong F., Elyas A.M., Ismail H., Mollah A.I., "Effects of export and technology on economic growth: Selected emerging Asian economies", Economic Research-Ekonomska Istraživanja, vol. 32, no. 1, pp. 2515-2531, 2019. DOI: 10.1080/1331677X.2019.1650656.

[13] Schotter A., Teagarden M. B., "Protecting Intellectual Property in China", MIT Sloan Management Review, vol. 55, no. 4, pp. 41-48, 2014.https://www.researchgate.net/publica tion/263698237_Protecting_Intellectual_Property_in_China
[14] Steffen B., Schmidt T., "A quantitative analysis of 10 multilateral development banks' investment in conventional and renewable power-generation technologies from 2006 to 2015", Nature Energy, vol. 4, no. 1., pp. 75-82, 2019. DOI: 10.1038/s41560-018-0280-3.

[15]"Take Action for the Sustainable Development Goals", Sustainable development goals, https://www.un.org/sustaina bledevelopment/sustainable-development-goals/. (accessed Feb. 2, 2021).

[16] Topp L., Mair D., Smillie L., Cairney P., "Knowledge management for policy impact: the case of the European Commission's Joint Research Centre", Palgrave Communications, vol. 4, no. 87, 2018. https://www.nature.c om/articles/s41599-018-0143-3.

[17]Wang H., "New Multilateral Development Banks: Opportunities and Challenges for Global Governance", Global Policy, vol. 8, no. 1, pp. 113-118, 2017. DOI: 10.1111/1758-5899.12396.

[18] AIIB. 2019 AIIB Annual report and financials. Available at: https://www.aiib.org/en/news-events/annual-report/2019/ho me/index.html

[19] ADB. Total ADB Operations 2020, by Sector and by Region. Available at: https://data.adb.org/media/7561

[20]ADB. Meeting Asia's Infrastructure Needs. Available at: https://www.adb.org/publications/asia-infrastructure-needs

[21] China's Belt and Road Initiative (BRI): What's in it for the world? Available at: https://www.refinitiv.com/content/dam /marketing/en us/documents/reports/refinitiv-zawya-belt-an d-road-initiative-report-2019.pdf

[22] Meibo Huang,, Na Chen, Yanhong Chen., "An analysis on the potential competitiveness of the Asian infrastructure investment bank" Asia-Pacific Development Journal Vol. 23, No. 2, 2016. Pp. 19-34. 